\title{
Impact Of Merger And Acquisition On Debt Management Ratio: A Case Study In Malaysian Banking Sectors
}

Mohammad Talha, Ph.D, (E-mail: mohammad.talha@mmu.edu.my) Multimedia University, Malaysia Abdullah Sallehhuddin, M.Phil, (E-mail: mohammad.talha@mmu.edu.my) Multimedia University, Malaysia

\begin{abstract}
This study based on efficiency theory of shareholder's wealth maximization of acquisition principle attempted to investigate the debt management ratio of ten Malaysian anchor banks after undergoing mega merger and acquisition program which was completed in the year of 2000. As efficiency theory consists of three elements that are financial synergy, operation synergy and managerial synergy, the study will primarily focus its analysis on financial synergy (debt management). Using accounting technique (financial statement analysis) to draw the implication, the study results highlighted the performance of those anchor banks from the year 2000 to 2004. The ratio analysis tools employed covered total liabilities to total assets, total liabilities to total equity, times interest earned, and cash debt coverage ratio. The findings shows that in general, the anchor banks recorded improvement in term of debt management; yet more comprehensive strategies have to be executed to further enhance the financial synergy. The generalization however shall be done in more cautious as the study inherits several limitations including the application of financial statement which based on historic cost rather than reflecting the current market situation. The study perhaps can be extended to include the analysis of earnings performance ratios and market/investor perception toward the resilience of those anchor banks after completing the merger and acquisition mega program.
\end{abstract}

\section{INTRODUCTION}

orporate restructuring is a broad term that describes several ways in which companies are organized. It refers to changes in capital structure, changes in ownership, merging companies together or breaking them a part (divestitures), modification of asset structures, and certain changes in methods of doing business. In addition, business failure and bankruptcy usually result in some kind of restructuring. Mergers are an important force in modern business. They've reshaped global industry several times in the last century, and continue to have a significant effect on companies and financial markets.

The terms 'merger', 'acquisition', and 'consolidation' all mean the combination of two or more business units under a single controlling ownership. In day-today practice, the word merger is loosely used to define any business combination, but technically each term refers to a particular type of transaction. A merger is a combination of two or more businesses in which all but one legally cease to exist, and the combined organization continues under the original name of the one surviving firm. A consolidation occurs when all of the combining legal entities dissolve, and a new one with a new name is formed to continue into the future. The merger situation is also called an acquisition. The term acquisition is used to describe any transaction in which a buyer acquires all or part of the assets and business of a seller, or all or part of the stocks or other securities of a seller. Within the general terms of acquisition, there are more specific forms of transactions, such as asset acquisition, stock acquisition, and take-over (Lasher, 2000)

An asset acquisition is a transaction in which the buyer acquires all or part of the assets and business of the seller while a stock acquisition is a transaction in which all or part of the outstanding stocks of the seller are acquired from the stockholders of the seller. A transaction is referred to as take-over when then acquiring company acquires 
control over the assets of the target company, either directly or indirectly through control of either the voting rights or the management of the target company. It involves a corporate control activity, which is the right to determine the management of corporate resources such as the right to hire or fire and to set the remuneration level of the managers (Lasher, 2000).

A take-over can occur in two ways; through tender offer and proxy contest. A tender offer occurs when a bidder makes an offer directly to shareholders to buy some or all of the shares of the target firm, while proxy contests occur when an insurgent group attempts to gain controlling seats on the board of directors. A sell off may either be a divestiture or a spin off. A divestiture involves the sale of a division or a subsidiary of one firm to another, in exchange for cash or other equivalent consideration. In a spin off, a new entity is formed from a division of the existing firm and it is given to the shareholders of the parent firm. Within mergers, consolidations and take-overs, there are specific forms such as management buyout (MBO) and leveraged buyout (LBO). MBO occurs when a group of investors, including members of the management of the target company, buys the target company directly. A special type of MBO is LBO that is generally used to describe high leverage acquisitions and restructuring. On the other hand, 'going private' refers to the purchase of the entire public stock interest of a firm by a group of private investors (Fauzias, 2003).

Take-overs can be classified into five main groups, namely, horizontal take-overs, vertical take-overs, congeneric take-overs, conglomerate take-overs and reverse take-overs. A horizontal take-over occurs when one firm takes over another that is in the same line of business. Vertical take-over involves related companies in a producersupplier relationship with both upstream and downstream businesses. Concentric take-over involves related companies but not producers of the same product (horizontal) or companies in producer-supplier relationship (vertical). A conglomerate take-over occurs when one company takes over another unrelated company. A reverse take-over occurs when a company acquires another company by exchanging shares resulting in a change in majority control of the acquiring company by the acquired company. The common end result is that the acquirer company obtains an indirect listing through the listed company, hence a reverse take-over is also commonly known as a back-door listing (Fauzias, 2003)

There could be many reasons behind a corporate restructuring. The most frequent observed motive is "economies of scale". As a company becomes large scale one, it can effectively compete with other large companies and the synergetic effects of the business combination may take the combined enterprise more effectual than the constituent entities individually. Though the most common explanations of acquisitions and merger is 'economies of scale", there may be other grounds for such combinations such as asset stripping, in which a company is solely acquired for selling its assets piece meal. It is usually happens when the acquired business is financially difficulties and cannot therefore continue as a going concern entity. Other reasons include cost savings, elimination of competition, acquiring management expertise, securing intellectual or property rights, gaining access to markets (local and international level), and straight $t$ forward earnings growth. In addition, where a small company is rapidly expanding where it becomes difficult to manage its operations, due to increasing complexity, it may wish to get acquired by a larger company.

Any theoretical analysis of acquisition involves an examination of the reasons and effects of acquisition. Firms can obtain operational as well as financial benefits as a result of acquisition. Dale (1973) suggested five primary rationales of growth by acquisitions, which include lengthening the product line, gaining shares in a market not previously supplied, enlarging a firm's capacity to supply old markets, diversifying interests and acquiring access to further processing or distribution facilities. Dale (1973) also further propounds that generally purely financial gains merely accompany an acquisition and are not a reason for affecting it. The shareholder's wealth maximization theory requires that a take-over or merger lead to increased profitability for the bidders as well as the target firms in order for the merger and take-over to be justified, notable from synergy; either from financial, operation or managerial synergy.

The principle value maximizing explanations of acquisition theory include efficiency theory, diversification of risk theory, coinsurance effect theory, merger and debt capacity, tax benefit theory, agency theory, asymmetric information theory, the monopolistic theory of acquisition, and the perfectly competitive acquisition market theory (Fauzias, 2003). 
Efficiency theory of shareholder's wealth maximization acquisition principle is viewed as being planned and executed to achieve three sources of synergy, which are financial synergy, operational synergy and managerial synergy. Gains in term of financial synergy are more in line with Mueller's neoclassical theories (1977). He proposed that financial synergy results in the ability to take advantage of each other's financial position. It results in either lower cost of capital, cost of debt, greater debt capacity or higher price-earnings ratio. In addition, investing in unrelated businesses will lower the systematic risk of a company's investment portfolio. The increased size of the firm will give it access to cheaper capital and reduce the probability of bankruptcy. Operational synergy results from economies of scale in production and distribution. Haley and Schall (1979) noted that the operational synergy has a direct effect on income and cash investment since the combined entities can produce lower cost product and sell the product more efficiently that results in higher revenue. Besides, the investment is greater since the merged entities can acquire capital equipment more cheaply and embark on a highly profitable investment program that enables income to exceed investment. Managerial synergy results when the bidder's manager possesses superior planning and monitoring abilities that benefit the target's performance. The cost of managing a large diversified firm, resulting from the formation of conglomerate especially, will substantially reduce relative to operating economies.

Given the arguments and analysis above, this study is conducted to investigate the impact or mergers and acquisitions on debt management ratio (financial synergy of efficiency theory). The study focuses the Malaysian's banking sector, which has undergone the mega restructuring program in 2000. The mega restructuring program has resulted in the formation of Malaysian ten anchor banks.

\section{OVERVIEW OF MALAYSIAN BANKING MEGA RESTRUCTURING PROGRAM}

With regard to Malaysian banking sector's merger and acquisition (M\&A) activities, the painful lesson of the recent Asian financial crisis where the viability of the economic sectors of the South East Asia countries were threatened, the Malaysian regulatory authorities have responded proactively (amongst other measures) by embarking on a program of strengthening the financial sectors. The authorities view that for the long-term survival and growth of Malaysian banking sectors, there is a need to organically increase the size of the various participants in the financial sectors. To achieve this objective, the Malaysian government has concertedly embarked on the program consolidating the number of various existing financial institutions. The effect of this exercise is to increase the financial base of each entity. Efficiency can be achieved through better management of a lesser number of institutions and the benefits of economics of scale can be achieved.

Malaysian Central Bank also known as Bank Negara Malaysia (BNM) master plan is to restructure the Malaysian banking sector by insisting the mega merger of 58 financial institutions in the year of 2000 (21 commercial banks, 25 finance companies and 12 merchant banks) into 10 anchor banks. One of the strongest impetuses for the plan is to ensure domestic banking institutions will be able to face liberalization of financial sector by the year 2003 as well as increasingly global competition environment. Secondly, the mega merger is implemented to withstand the possible financial crisis as experienced previously (1987 and 1998). The creation of anchor banks provides greater confidence among depositors as well as making these banks stronger and more resilient. The following Table 1 lists the Malaysian anchor banks after M\&A process.

Table 1: Malaysian 10 Anchor Banks

\begin{tabular}{|c|c|l|}
\hline \multicolumn{1}{|c|}{ Anchor Bank } & \multicolumn{1}{c|}{ Banking Institutions in Group } \\
\hline & $\bullet$ & Malayan Banking Berhad \\
& $\bullet$ & Mayban Finance Berhad \\
Malayan Banking Berhad & $\bullet$ & Aseambankers Malaysia Berhad \\
& $\bullet$ & PhileoAllied Bank Berhad \\
& $\bullet$ & The Pacific Bank Berhad \\
& $\bullet \quad$ Sime Finance Berhad \\
& $\bullet \quad$ Kewangan Bersatu Berhad \\
\hline
\end{tabular}




\begin{tabular}{|c|c|}
\hline Bumiputra-Commerce Bank Berhad & $\begin{array}{ll}\text { - } & \text { Bumiputra-Commerce Bank Berhad } \\
\text { - } & \text { Bumiputra-Commerce Finance Berhad } \\
\text { - } & \text { Commerce International Merchant Bankers Berhad } \\
\end{array}$ \\
\hline RHB Bank Berhad & $\begin{array}{ll}\text { - } & \text { RHB Bank Berhad } \\
\text { - } & \text { RHB Sakura Merchant Bankers Berhad } \\
\text { - } & \text { Delta Finance Berhad } \\
\text { - } & \text { Interfinance Berhad } \\
\end{array}$ \\
\hline Public Bank Berhad & $\begin{array}{ll}\text { - } & \text { Public Bank Berhad } \\
\text { - } & \text { Public Finance Berhad } \\
\text { - } & \text { Hock Hua Bank Berhad } \\
\text { - } & \text { Advance Finance Berhad } \\
\text { - } & \text { Sime Merchant Bankers Berhad } \\
\end{array}$ \\
\hline Arab Malaysian Bank Berhad & $\begin{array}{ll}\text { - } & \text { Arab-Malaysian Bank Berhad } \\
\text { - } & \text { Arab-Malaysian Finance Berhad } \\
\text { - } & \text { Arab-Malaysian Merchant Bank Berhad } \\
\text { - } & \text { Bank Utama Malaysia Berhad } \\
\text { - } & \text { Utama Merchant Bankers Berhad } \\
\end{array}$ \\
\hline Hong Leong Bank Berhad & $\begin{array}{ll}\text { - } & \text { Hong Leong Bank Berhad } \\
\text { - } & \text { Hong Leong Finance Berhad } \\
\text { - } & \text { Wah Tat Bank Berhad } \\
& \text { Credit Corporation Malaysia Berhad } \\
\end{array}$ \\
\hline Perwira Affin Bank Berhad & $\begin{array}{ll}\text { - } & \text { Perwira Affin Bank Berhad } \\
\text { - } & \text { Affin Finance Berhad } \\
\text { - } & \text { Perwira Affin Merchant Bankers Berhad } \\
\text { - } & \text { BSN Commercial Bank Berhad } \\
\text { - } & \text { BSN Finance Berhad } \\
\text { - } & \text { BSN Merchant Bank Berhad } \\
\end{array}$ \\
\hline Multi-Purpose Bank Berhad & $\begin{array}{ll}\text { - } & \text { Multi-Purpose Bank Berhad } \\
\text { - } & \text { International Bank Malaysia Berhad } \\
\text { - } & \text { Sabah Bank Berhad } \\
\text { - } & \text { MBf Finance Berhad } \\
\text { - } & \text { Bolton Finance Berhad } \\
\text { - } & \text { Sabah Finance Berhad } \\
\text { - } & \text { Bumiputra Merchant Bankers Berhad } \\
\text { - } & \text { Amanah Merchant Bank Berhad } \\
\end{array}$ \\
\hline Southern Bank Berhad & $\begin{array}{ll}\text { - } & \text { Southern Bank Berhad } \\
\text { - } & \text { Ban Hin Lee Bank Berhad } \\
\text { - } & \text { Cempaka Finance Berhad } \\
\text { - } & \text { United Merchant Finance Berhad } \\
\text { - } & \text { Perdana Finance Berhad } \\
\text { - } & \text { Perdana Merchant Bankers Berhad } \\
\end{array}$ \\
\hline EON Bank Berhad & $\begin{array}{ll}- & \text { EON Bank Berhad } \\
\text { - } & \text { EON Finance Berhad } \\
\text { - } & \text { Oriental Bank Berhad } \\
\text { - } & \text { City Finance Berhad } \\
\text { - } & \text { Perkasa Finance Berhad } \\
\text { - } & \text { Malaysian International Merchant Bankers Berhad }\end{array}$ \\
\hline
\end{tabular}


Bank Negara Malaysia's move is seen as an effort to ensure domestic banking institutions shall be able to face pressures and challenges arising from globalization and from an increasing competition in global environment. Tan Sri Dr. Zeti Ungku Aziz, the Governor said that the anchor banks were created so that they were able to withstand the financial crisis. She pointed out that at the height of the recent crisis, depositors of the smaller banks themselves felt unsafe and moved their savings to the bigger banks. The objectives of the mergers include creation of a core group of domestic bank. This practice has been carried out in several countries like United States, Canada, Australia and Singapore, which aims to make these banks stronger and more resilient. Such merger and acquisition program is expected to derive several benefits including (1) larger banks will be easier to be regulated, theoretically reducing the like hood of a surprise failure, (2) economies of scale should make the banks more efficient and more profitable, (3) larger banks will be able to issue debt in sizes sufficient to justify tapping international markets, both giving investors a wide range of investment choices and increasing funding options for Malaysian banks, and (4) as they increase in size, Malaysian banks are more likely to take international ratings, improving the transparency of the financial system.

\section{PRIOR RESEARCH}

Fauzias (1995), in her study on post performance of Malaysian acquired firms, uses accounting based measures to draw implications regarding the performance of acquired firms. The results are based on the average of five years before and after the take-over. The study showed that the acquisition of public listed companies did not result in improvement in the earnings performance after the take-over. Contrary to the actual performance of the companies, the investors' perception on the value of the target increased. The decline in earning performance ratio could be explained by the fact that all target samples except one are of a conglomerate type. In addition, most of these acquisitions have been financed by the issue of shares by the bidder to the target's shareholders, resulting into dilution of earning performance.

Izma (1999) in her study highlighted the causes of banking merger. First reason is the banks are trying to trim costs by gaining economies of scale. Buy or merge with another bank and create that scale by cutting staff and combining customer bases, assets and products. Other reason is the banks are too subscaling thus merging banks made external parties attracted. On consolidation process these mergers are supposed to produce bigger and healthier offspring that are able to vie tooth and nail against their peers in a global arena. The author have used one of Concurs Fawcett quote where merging is not maintaining the status quo but trying to move up to the next level. Fawcett also have estimated that 50 to 75 percent failure rate due to underlying reasons like conflicting or incompatible cultures doing inadequate homework before merging and paying unrealistic premium for acquisitions. One of financial goals is cost cutting. According to Fawcett, costs saving opportunities are derived both from scale/scope economies and upgrading process. Other point highlighted by the writer is that the good mergers don't only slash cost and boost market but also means to mitigate risk. Mitigation risk could give more benefit but not work well in Asia. The risk technically occurred when banks combine their portfolios and they diversify their risk over a greater number of industries and borrowers. In Asia the procedure are different and make a merged entity might end up with double the exposure to a single client. The important point that the writer has highlighted is the important of information technology (IT) in the banking sector. By using IT or using the application of computer will change overall performance of the banking sector. According to the author the bigger the bank, the cheaper it is to implement and use IT innovations since transaction unit cost decrease with volume. Information technology is becoming the great leveler, enabling costs to be slashed to the bare minimum and in very extreme cases eliminating conventional brick and mortar banking. The most successful user in using the information technology is USA where have full application on online banking (e-banking) for their transaction in banking sector. However Malaysia still not fully prepared to use the ebanking because of the fact that only 600000 Internet users compared to 20 million populations. The limitation of this study is that it failed to discuss the more point about the overall performance of the merger impacts in banking sector merger. Other than that the author has too much discussed about the cause of the merger was it seem like to be redundancy point on one to two paragraph for example.

According to an article published by Bank Negara Malaysia (BNM), extracted from The Star (one of Malaysian leading English newspaper), dated August 11, 1999, the merger and acquisition exercise between the banking institutions will not weaken the financial strength of the merged entities. In fact, the merger has created six domestic financial groups that ensure the domestic banking institutions will be able to hold the pressures and 
challenges from globalisation and competitive environment. Business consolidation through merger is indeed a common practice globally to achieve economies of scale and higher productivity. The need to merge is even more imperative in the face of increasing pressure under World Trade Organisation (WTO) for countries to open up their financial markets to further entry of foreign banks. The literature stated that, this move towards consolidation is in line with the Government's policy not to bail out weak companies but to rationalise businesses towards higher productivity. This is due to economic recession and banking crisis in mid-1980s where a number of weak commercial banks and finance companies into insolvency and financial distress. They were saddled with high level of nonperforming loans (NPL), the result of over-lending to the property sector and careless exposure to share-based lending during the earlier boom years. Therefore, BNM had to implement a rescue scheme. This involved BNM acquiring shares in some of the weakly commercial banks and the absorption of the assets and liabilities of the insolvent finance companies by stronger finance companies. As a result, the number of finance companies was reduced from 47 to 40 . The mergers were thus driven by the rescue scheme in order to restore stability in the banking sector. Despite the progress achieved thus far in bank restructuring, the non-performing loans (NPL) still remain large. For instance, on the gross basis, the NPL of the banking system amounts to RM72 billion on 3-month basis and RM53billion on 6month basis. The problem faced by smaller financial institutions and the only viable solution is for a merger, which removes smaller financial institutions from the market. At the same time, the merger allows for smaller financial institutions to participate in a much larger banking group. To the extent all the six banking groups are listed, anybody can buy bank shares from the market. Finally, the announcement on the merger exercise has always been welcomed in all parts of the world. BNM will undertake to do whatever it can to make this merger exercise a success. The limitation of this literature is it focuses too much on the problems that occur before the merger and acquisition between the banking institutions. The literature also failed to consider the other factors or problems before the mergers. Besides, it only focused on way to financing especially on the smaller financial institutions. In addition, the literature also did not illustrate further on how the implication on other aspects after the mergers and acquisitions.

Shamsudin and Fauziah (2000), evaluate the effect of the recent bank mergers in Malaysia on the following variables: competition bank employee, small and medium sized industries (SMIs), retail customers, capital adequacy and capital requirement. The study concludes that the relevant authorities have overlooked the dire consequences of such mergers on the above- mentioned variables. The writer in the introduction part have discussed about the advantage and benefit of the merger. Other than that the writer have raised the point of Dr Zeti in Bernama (Malaysian's National News Agency), has said the anchor bank were chosen because they were able to withstand the recent financial crises. The second part has been discussed by the writer is the effect on bank customer. Three main idea have been argued by the writer, first is the introduction of priority banking may be advertised as a bank marketing strategy but many strategy is regarded as discrimination banking and such strategy is regarded as antithesis to our socalled caring society. Then the writers had highlighted the establishment of CGC known as Credit Guarantee Corporation by BNM where the factor of the establishment is because the problems of getting credit from commercial bank. Final point of the second part is the rural folks will face the problem to travel to the bigger town for make transaction with the bank. The third part discussed about the bank employee. The writers had highlighted the point where there is cost saving to bank in manpower translate to unemployment and forced retrenchment. The point highlighted the research topic is in the fourth part where the writers discussed about the banking sector merger. The assumption made by the author is that profitable consistent with the effects of synergy. The effect of bank merger on financial institutions in Malaysia is also mixed. Mergers between small banks appear to increase lending to small business, but mergers between larger banks generally decrease this type of lending or leave it unaffected. Shanmugan (2000), states that although there are many indicators to gauge the size of bank, the normal benchmark is asset size. But this may not be an appropriate indicator at present, when the economy is coming out of a downturn. He indicates that the asset may be large but may be suspect. The merger process is also seen as method of achieving the minimum capital requirement of Bank Negara. The Capital Adequacy Requirement (CAR) ratio recognizes that investments in bank asset have different levels of risk and high CAR ratio requires higher levels of capital to support the relevant investment. The direct effect is that banks have to charge a higher price for those assets to reflect the opportunity cost of the additional capital required. Once again, bank customers are burdened with the additional cost. Finally the writer have concluded that the banking merger in Malaysia are merged because of economic constraint compare to the Japan banking merger done on their own accord to lead the banking world. The limitation of this study is to discuss very less about the merger impact on the banking sector in shareholder and overall performance. Other than that the author failed to support the conclusion given with the material or point that they have highlighted. 
Another study conducted by M Shanmugan (2000), in his study on merger in Malaysian financial sector highlighted the issue of shareholders approval would be needed before the amalgamation would be taken place. Other than that Danaharta mopping up all of Bank Bumiputra Malaysia (BBMB) bad loans hastened the latest merger between Bank of Commerce and Bank Bumiputra Malaysia (BBMB) process. Besides, the majority shareholder of Bank Bumiputra Malaysia Bhd (BBMB) is the Ministry of Finance and thus was easier to deal with. Compared to one or three year's age the interest is high in it priced. But now the price is at the lower end of scale. It really impacts the shareholders of the entity. The author has focused about tight schedule that have bee planned by Bank Negara for the merger of banking sector. Actually Bank Negara have tried to cajole banks into merging since 15 years later. But there is difficulties such as fraud in exercising make the merging unsuccessful. Anchor bank has been the most important role in merging situation. The role of anchor bank is aiding the smaller bank or smaller asset by merging. The most difficult merger was involving Multi Purpose Bank and Affin Bank (the merger was not materialized). The former will be taking over among others RHB Bank, which is some six times larger with assets of about RM 60 billion. The limitation of this study is it failed to rise up more impact to the shareholder for the merging in banking sector. The author has discussed more example of merger but failed to prove of financial on banking merger. For example is the merger of Multi Purpose Bank and Affin Bank where the author think that the merging acquiring the operations of the Arab-Malaysian Group an outfit twice its size but not discussed the amount of asset acquired.

\section{RESEARCH METHODOLOGY}

In the earlier part of the paper, it has been acknowledged that one of the motives that move company for merger and acquisition activities is efficiency theory. This theory views a merger as being planned and executed to achieve synergies These synergies can arise from three sources; financial, operational and managerial synergy. Mueller (1969), however, notes that the synergistic effects of a merger will take place only when they produce some increase in market power, or when they produce a technological or managerial economy of scale. However, in a conglomerate merger, most of the theoretical literature of finance has assumed no synergy, except for financial effects (Copeland and Weston, 1988). The financial possibilities include taking advantage of transient errors in the market valuation of acquisition candidates, utilizing the unused debt capacity of an acquired firm subsequent to merger, or simply obtaining a diminished variability of total corporate earnings through the portfolio diversification implied by conglomeration (Lewellen, 1971).

Another theory relating to motivation for merger and acquisition is an agency theory. Jensen and Meckling (1976) have developed a comprehensive theory of agency costs. They show that the principal such as the stockholders can assume that the agent (manager) will make optimal decisions only if appropriate incentives are given, and only if the agent is monitored. Thus the separation of ownership and control in a company will give rise to so called agency cost. It reflects the economic losses to shareholders when management does not act in the shareholders' best interest including maximizing the market value of the owner's equity. Jensen and Meckling (1976) also suggest that the value of company reflects a valuation by shareholders to include the value perquisites consumed by the managers as agents of the shareholders. In other word, they suggest that top management remuneration should reflect organization performance and shareholder's return. Fama (1980) suggests that the primary monitoring of mangers comers not from the owners but from the managerial labor market. If the managerial labor market is competitive both within and outside the company, it will tend to discipline the manger. The market for corporate control, a major component of the managerial labor market, and often referred to as the take-over, is the arena in which alternative management teams compete for the right to manage corporate resources (Jensen and Riback, 1983).

As for this study, the theoretical framework is derived from efficiency theory, which is one of the principal value explanations of acquisition theory. The efficiency will be focused on the financial synergy (performance of debt management ratio) obtained by the 10 Malaysian anchor banks after undergoing merger and acquisition program in the year 2000. The figure representing theoretical framework of the study is given in Appendix 1. The data was collected from the ten anchor bank groups' annual report from 2000 - 2004. Data collected include prices of shares both high and low, net profit, paid up capital, gross profit, interest on long term liabilities, retained earnings, total current liabilities, long term liabilities and total reserves. The data was collected for each acquired anchor banks for a period of four years after merger and acquisition activities. The name of the 10 anchor banks is listed in Appendix 2. The primary source of data is the annual report of ten anchor banks, which are listed on Malaysian Bourse's main 
board under financial sub sector. Those annual reports are collected from the bourse's website, resource center and the banks' online annual report available on their website. From these sources, the information gathered for all financial performance in the final reporting sample is presented in Appendix 3. This study acknowledges that those banks frequently disclose information through other channels, such as the media, interim financial statements, and preliminary announcements to the stock exchange. However, such forms of information disclosure are outside the scope of this study.

Given a large amounts of debt frequently associated with merger and acquisitions. Financial leverage ratios become a very useful financial analysis tool for the merger analyst. The financial leverage or debt ratios indicate the degree of financial leverage that the firm has assumed. Financial leverage refers to the amount of debt the firm has used relative to the equity in its total capitalization. In merger and acquisition, the analyst must compute the financial leverage ratios based on different assumption regarding the total debt used to finance the acquisition. These resulting debt levels are then compared with industry norms and standards to reveal how the merged firm compares with other firms in the industry. A merger and acquisition often results in a firm's being well above the industry average (financially synergize). When the acquirer has plans to "pay down" the debt following the acquisition by assets sales, the financial ratios should be projected for several years to determine the impact of the debt retirement. In this case, the analyst would like to determine how long it takes until the leverage ratios return to industry norms.

For the purpose of this study, a comparison of the difference in capital structure as a measure of financial leverage after merger and acquisition process is determined by the ratio of total liabilities to total assets (TLOTA), total liabilities to total equity (TLOTE), times interest earned (TIE), and cash debt coverage ratio (CDCR). These are determined by the following formula:-

TLOTA $=\frac{\text { Total liabilities }}{\text { Total assets }}$
TLOTE $=\frac{\text { Total liabilities }}{\text { Shareholder's fund }}$
TIE $=\frac{\text { Gross earnings }}{\text { Interest charges }}$
$\mathrm{CDCR}=\frac{\text { Net cash provided by operating activities }}{\text { Total liabilities }}$

The results are based on five years after merger and acquisition (2000, 2001, 2002, 2003, and 2004). TLOTA is also known as debt ratio. It is sometimes computed by adding together short-term debt and long-term debt. The debt ratio indicates the firm's ability to service its debt. Obviously, creditors want this ratio to be low, since the lower the ratio, the greater the cushion against creditor's losses in the event of liquidation. In contrast to the creditors' preference for a low debt ratio, the owners may seek high leverage either (1) to magnify earnings or (2) because raising new equity means giving up some degree of control. If the debt ratio is too high, there is a danger of encouraging irresponsibility on the part of the owners. The stake of the owners can become so small that speculative activity, if it is successful, will yield a substantial percentage return to the owners. If the venture is unsuccessful, however, only a moderate loss is incurred by the owners because their investment is small. An acquirer may consider a target firm with a relatively larger amount of marketable fixed assets and a low debt ratio to be an ideal takeover target. Such a firm may have much unused borrowing capacity and may be vulnerable to takeover. Companies with low debt ratios relative to the industry, recognizing their own vulnerability, may load up on debts. A debt ratio of 0.65 , for example, means that the firm has financed $65 \%$ of its assets by using debt (Caughan, 2002).

TLOTE is also known as the debt-equity ratio. It is more often quoted financial leverage ratios. Preferred share is commonly added to liabilities in the computation because preferred share are somewhat fixed. A firm cannot be forced into receivership if preferred share payments are not made. It is usually assumed, however, that the firm has every intention of making these payments when the debt is issued. Therefore, they usually are treated as fixed. This is 
why preferred share is more like debt than equity and is often categorized with fixed income securities. It is difficult to judge a good debt-equity ratio without analyzing the firm's cash flows. Firms with very stable cash flows can more predictably handle higher debt levels. If an acquirer is considering taking over a target and financing the acquisition primarily with debts, a cash flow analysis needed to be conducted. If the cash flows are volatile, an added element of risk is introduced. A debt-equity ratio of 0.67 , for example shows that the firm's liabilities is only $67 \%$ as large as its equity (Caughan, 2002).

TIE or times interest earned ratio is determined by dividing gross income by the interest charges. The ratio measures the extent to which earnings can decline without resultant financial embarrassment to the business entities to meet annual interest costs. Failure to meet such obligation can bring legal action by the creditors, possibly resulting in bankruptcy. Note that the before tax figure is used in the numerator. As income taxes are computed after interest expense is deducted, the ability to pay current interest is not affected by income tax. TIE is also known as coverage ratio. For instance, if gross earning is 1000 and interest is 100 , so that TIE is 10 . We would imply that interest is covered 10 times. Clearly, the more times earnings cover existing interest, the safer it is to lend the firm more money (Weston and Brigham, 1975)

There is an obvious problem with previous TIE ratio. Interest is a cash payment; however gross income is not perfectly a source of cash. In fact, it is an income statement subtotal that may be considerably different from cash flow. In other words, more or less cash that gross income may be available in any given year to pay interest. A better estimation of coverage is available with introduction of cash debt coverage ratio (CDCR). This ratio demonstrates a firm's ability to repay its liabilities from cash generated from operating activities, without having to liquidate the assets employed in its operation.

\section{FINDINGS AND ANALYSIS}

Table 2 and Table 3 show the difference in capital structure performance as a measure of financial leverage after the merger and acquisition program. Table 2 indicates the ratio of total liabilities to total assets (TLOTA), while Table 3 shows the ratio of total liabilities to shareholder's fund (TLOTE). Table 4 highlights the times interest earned performance, while Table 5 focuses the cash debt coverage ratio performance of the anchor banks.

Table 2: Total Liabilities to Total Assets Performance

\begin{tabular}{|l|c|c|c|c|c|}
\hline \multicolumn{7}{|c|}{ Total Liabilities to Total Assets (TLOTA) } \\
\hline & $\mathbf{2 0 0 0}$ & $\mathbf{2 0 0 1}$ & $\mathbf{2 0 0 2}$ & $\mathbf{2 0 0 3}$ & $\mathbf{2 0 0 4}$ \\
\hline Affin Bank & 0.89 & 0.93 & 0.93 & 0.92 & 0.91 \\
\hline AMB & 0.93 & 0.92 & 0.93 & 0.93 & 0.92 \\
\hline Alliance & 0.77 & 0.94 & 0.94 & 0.92 & 0.92 \\
\hline BCB & 0.92 & 0.92 & 0.92 & 0.91 & 0.91 \\
\hline EON & N/A & N/A & 0.94 & 0.93 & 0.92 \\
\hline Hong Leong & 0.93 & 0.93 & 0.92 & 0.91 & 0.91 \\
\hline Maybank & 0.92 & 0.93 & 0.92 & 0.91 & 0.92 \\
\hline Public Bank & 0.88 & 0.86 & 0.87 & 0.86 & 0.90 \\
\hline RHB & 0.99 & 0.99 & 0.94 & 0.93 & 0.94 \\
\hline SBB & 0.91 & 0.91 & 0.90 & 0.91 & 0.89 \\
\hline Mean & 0.904 & 0.926 & 0.921 & 0.913 & 0.914 \\
\hline Std Deviation & 0.059 & 0.034 & 0.021 & 0.020 & 0.013 \\
\hline Variance & 0.004 & 0.001 & 0.0005 & 0.0004 & 0.0001 \\
\hline
\end{tabular}

N/A: not available

The mean of total liabilities to total assets (TLOTA) of the ten anchor banks is 0.897 in 2000. It reflected that in the particular year $89.7 \%$ of banks' investment is provided through debt (long term liabilities elements and short term elements). The mean increased to 0.924 (2001) before dropped to 0.921 (2002) and further improved to 0.913 
(2003). However, the mean slightly increased to 0.914 (2004). The findings highlighted that, more than $90.0 \%$ of Malaysian anchor banks' investment is financed by creditors. In term of individual performance, Public Bank Berhad recorded result below the group's mean for five consecutive years (2000-2004), after completing the merger and acquisition program. In addition, Bumiputera Commerce Berhad and Southern Bank Berhad marked better total liabilities to total assets performance starting 2001-2004 since the completion of mega restructuring program in 2000. For total liabilities to total equity performance, the mean in 2000 is 18.569 , then ballooned to 26.533 (2001), before shrinking to 14.175 (2002), 11.973 (2003) and 11.755 (2004) respectively. These figures showed that the management of post merger and acquisition era has undertaken comprehensive strategy to improve the debt management, thus narrowing the ratio of total liabilities (long term debts and short debts) to equity in funding the operational and expansion of those anchor banks. As individual performance, Bank Bumiputera Commerce, Hong Leong Bank, Maybank, Public Bank and Southern Bank Berhad, have took necessary strategies to ensure their ratios are below the group's ratio since 2000 till 2004. The trend shows in the following Table 3.

Table 3: Total Liabilities to Total Equity Performance

\begin{tabular}{|l|c|c|c|c|c|}
\hline \multicolumn{7}{|c|}{ Total Liabilities to Total Equity (TLOTE) } \\
\hline & $\mathbf{2 0 0 0}$ & $\mathbf{2 0 0 1}$ & $\mathbf{2 0 0 2}$ & $\mathbf{2 0 0 3}$ & $\mathbf{2 0 0 4}$ \\
\hline Affin Bank & 8.69 & 15.24 & 14.59 & 13.54 & 11.19 \\
\hline AMB & 18.68 & 16.99 & 20.74 & 15.72 & 13.49 \\
\hline Alliance & 6.62 & 22.69 & 23.28 & 11.82 & 12.24 \\
\hline BCB & 12.53 & 12.45 & 12.19 & 11.29 & 11.62 \\
\hline EON & N/A & N/A & 15.53 & 12.67 & 11.99 \\
\hline Hong Leong & 12.98 & 12.62 & 11.67 & 10.15 & 10.09 \\
\hline Maybank & 11.24 & 13.0 & 11.80 & 10.59 & 10.92 \\
\hline Public Bank & 8.96 & 7.25 & 7.85 & 6.43 & 9.7 \\
\hline RHB & 90.77 & 151.5 & 14.88 & 16.72 & 18.25 \\
\hline SBB & 10.65 & 9.88 & 9.22 & 9.80 & 8.06 \\
\hline Mean & 20.124 & 29.069 & 14.175 & 11.873 & 11.755 \\
\hline Std Deviation & 26.712 & 46.120 & 4.818 & 2.992 & 2.732 \\
\hline Variance & 713.507 & 2127.056 & 23.213 & 8.954 & 7.463 \\
\hline
\end{tabular}

N/A: not available

Table 4: Times Interest Earned Performance

\begin{tabular}{|l|c|c|c|c|c|}
\hline \multicolumn{7}{|c|}{ Times Interest Earned Ratio (TIE) } \\
\hline & $\mathbf{2 0 0 0}$ & $\mathbf{2 0 0 1}$ & $\mathbf{2 0 0 2}$ & $\mathbf{2 0 0 3}$ & $\mathbf{2 0 0 4}$ \\
\hline Affin Bank & -0.789 & -11.288 & 4.292 & 3.172 & 6.323 \\
\hline AMB & 0.499 & 0.437 & 0.289 & 0.241 & 0.220 \\
\hline Alliance & 0.663 & 0.062 & 0.250 & 0.385 & 0.503 \\
\hline BCB & 0.399 & 0.256 & 0.375 & 0.490 & 0.424 \\
\hline EON & N/A & N/A & 0.53 & 0.542 & 0.50 \\
\hline Hong Leong & 0.578 & 0.534 & 0.654 & 0.775 & 0.519 \\
\hline Maybank & 0.567 & 0.372 & 0.691 & 0.796 & 1.044 \\
\hline Public Bank & 1.047 & 1.036 & 1.032 & 1.125 & 1.237 \\
\hline RHB & 1.482 & 0.450 & 0.332 & 0.336 & 0.315 \\
\hline SBB & 0.462 & 0.526 & 0.656 & 0.751 & 0.717 \\
\hline Mean & 0.545 & -0.846 & 0.910 & 0.861 & 1.180 \\
\hline Std Deviation & 0.573 & 3.70 & 1.15 & 0.81 & 1.741 \\
\hline Variance & 0.369 & 15.402 & 1.469 & 0.729 & 3.365 \\
\hline
\end{tabular}

N/A: not available 
Referring Table 4, the average of times interest earned was 0.545 (2000). However, the ratio recorded negative result that was -0.846 (2001). This negative result was contributed by less impressive of gross earning recorded during the year by those banks. The ratio improved since then with 0.910 (2002) and 0.861 (2003) and it reached desirable ratio 1.180 (2004). The mean of 1.180 in 2004 indicated that in average the anchor banks experience better capacity to serve their interest commitment using the available gross earnings amount. In term of individual performance, once again Public Bank Berhad recorded impressive times interest earned, which is 1.047 (2000), 1.036 (2001), 1.032 (2002), 1.125 (2003), and 1.237 (2004). Definitely, most if not all business entities wish to have greater times interest earned ratio as lower figure provides skeptical among investors or markets on their capabilities to cover interest.

Table 5: Cash Debt Coverage Ratio Performance

\begin{tabular}{|l|c|c|c|c|c|}
\hline \multicolumn{7}{|c|}{ Cash Debt Coverage Ratio } \\
\hline & $\mathbf{2 0 0 0}$ & $\mathbf{2 0 0 1}$ & $\mathbf{2 0 0 2}$ & $\mathbf{2 0 0 3}$ & $\mathbf{2 0 0 4}$ \\
\hline Affin Bank & 0.041 & -0.058 & 0.073 & 0.132 & -0.076 \\
\hline AMB & 0.053 & 0.039 & 0.005 & 0.003 & 0.053 \\
\hline Alliance & 0.361 & -0.034 & 0.025 & 0.053 & 0.065 \\
\hline BCB & -0.097 & -0.013 & 0.032 & 0.011 & 0.001 \\
\hline EON & N/A & N/A & 0.02 & 0.022 & -0.03 \\
\hline Hong Leong & 0.034 & 0.005 & 0.039 & -0.003 & 0.195 \\
\hline Maybank & 0.047 & -0.032 & 0.025 & 0.013 & 0.048 \\
\hline Public Bank & -0.031 & -0.019 & 0.038 & -0.020 & 0.111 \\
\hline RHB & 0.025 & -0.002 & -0.001 & 0.032 & 0.152 \\
\hline SBB & 0.057 & -0.002 & 0.0001 & 0.099 & -0.04 \\
\hline Mean & 0.054 & -0.013 & 0.026 & 0.034 & 0.048 \\
\hline Std Deviation & 0.125 & 0.028 & 0.022 & 0.048 & 0.087 \\
\hline Variance & 0.016 & 0.001 & 0.005 & 0.002 & 0.008 \\
\hline
\end{tabular}

N/A: not available

Table 5 shows the cash debt coverage ratio. The ratio performance of those anchor banks indicated average of 0.054 (2000), before it turned negative with -0.013 (2001). The less impressive performance was parallel to the performance showed by times interest earned during the particular year. However, there was improving sign with 0.026 (2002), 0.034 (2003), and 0.048 (2004). Such improvement demonstrated the anchor banks' ability to repay their liabilities from cash generated from operating activities, without having to liquidate the assets employed in its operation. Even though the average of 2004 recorded 0.048, in term of individual performance, Southern Bank Berhad, EON Bank Berhad and Affin Bank Berhad recorded -0.04, -0.03 and -0.076 respectively. Therefore, the new management must carry out comprehensive strategy to enhance the generation of cash from operating activities or further improved the debt management.

\section{SUMMARY AND CONCLUSION}

The study showed that the merger and acquisition of Malaysian banking sector in general, did result in improvement in debt management ratio (showed in Table 2, 3, 4, and Table 5). However, management of individual anchor banks must continue to work harder and improve further in certain areas such as; generating more cash from operating activities, optimize the utilization of assets, reduce dependency on credits for expansion purpose, well mixed the financing sources combination between long-term and short-term debt with equity generated. Nevertheless, we believe that the success of individual acquisition will depend upon the abilities of the new management of the anchor banks to achieve operational efficiency and to make shifts in their product markets required by the changing economic environment as professed by Fauzias (1995), which will then be reflected in its actual earning performance and the value of the firm.

However, the study inherited several limitations that distort the accuracy of the ratio analysis. Firstly, the study excludes the comparisons of how the market or investors perceives a bank's growth and profit opportunities 
after the merger and acquisition programs. These perceptions can be determined by adopting formula of priceearnings ratio $(\mathrm{P} / \mathrm{E})$, multiples of asset or the ratio of market value of the firm (equity + debt) to the replacement cost of the bank's assets (Tobin's q), and multiples of book value or market value to book value ratio (MTBV). Secondly, the analysis and the findings of the study could be enhanced with the incorporation of earning performance of those anchor banks after undergoing merger and acquisition mega restructuring program. Earning performance analysis would enhance the study as it measures efficiency gains with the introduction of earning per share (EPS), return on equity (ROE), return on capital employed (ROCE), and return on total assets (ROTA). In addition, the analysis in this study is based on financial statements that are normally available publicly by virtue of legal filing requirements for publicly held companies like those ten anchor banks. A standard set of financial statements includes an income statement, a balance sheet, and a statement of cash flows. The merger analyst reviews these statements over a selected historical time period and derives various financial measures that are used in the valuation analysis. Thus, the value of much of this financial analysis depends on the quality of the available financial data. Friendly transactions tend to feature greater disclosure between the two parties. In a hostile takeover, however, the target will only disclose the minimum as required by the authority bodies and governing institutions. Besides, financial statements contain numerous estimates. Estimates, for instance are used in determining the costs of warranties and contingent losses. To the extent that these estimates are inaccurate, the financial ratios and percentages are inaccurate. Secondly, traditional financial statements are based on history cost and are not adjusted for price level changes. Comparisons of unadjusted financial data from different periods may render invalid by significant inflation or deflation. Thirdly, variations among banks in the application of financial reporting may hamper comparability. In addition to differences in costing methods, differences also exist in reporting such items as debt write off, depletion and amortization. Although these differences in accounting methods might be detectable from reading the notes to the financial statements, adjusting the financial data to compensate for the different methods is difficult, if not impossible in some cases. Next, fiscal year end date may not be typical of the financial condition during the year. Firms frequently establish a fiscal year end that coincides with the low point in operating activity. Therefore, certain account balances may not be representative of the balances in the accounts during the year.

With regard to merger and acquisition in Malaysian banking sectors, several studies can be carried out in future. Firstly, the similar study could be enhanced by introducing fresh methodology and research design, particularly employing analysis tools that reflect the market/investors perception as well as earnings performance analysis. The similar study may be conducted with different theoretical framework especially incorporating other theories of shareholder's wealth maximization such as efficiency theory (operational and managerial synergy), diversification of risk theory, coinsurance theory, merger and debt capacity theory, agency theory, asymmetric information theory, tax benefits theory, the perfectly competitive acquisition theory and the monopolistic theory of acquisition. In addition, this study is hoped to encourage more comprehensive in merger and acquisition area such as acquisition announcement and stock price behavior, valuation and paying for take-over, and prediction of corporate take-over.

\section{REFERENCES}

1. Caughan, P.A. 2002. Mergers, Acquisitions, and Corporate Restructurings. United States of America. Wiley.

2. Copeland, T.E., \& Weston, J.F. 1988. Financial Theory and Corporate Policy United States of America: Addision-Wesley.

3. Dale, P.M. 1973. A financial survey of mergers during the year 1968-70. The International Journal of Management Science, vol.1, no.3 February, 2305-315.

4. Fama, E.F. 1980. Agency Problems and the Theory of Firm. Journal of Political Economy 88: 288-307

5. Haley, C.W. \& Schall, L.D. 1979. The Theory of Financial Decisions. United States of America: McGrawHill Book Company.

6. Ismail, Shamsudin \& Mahat, Fauziah. 2000 (October). A Critical Evaluation of the recent mega Bank mergers in Malaysia. Proceeding of Economics and Management Faculty Seminar: Issues in Accounting and Finance 2, 20 - 23. Malaysia:Universiti Putra Malaysia.

7. Izma, Nazatul. 1999. The reality of mergers. Journal of Malaysian Business. Vol. 3, 49-51.

8. Jensen M.C. \& Ruback R.S. 1983. The Market for Corporate Control - The Scientific. Journal of Financial Economics 11: 225-237. 
9. Jensen M.C \& Meckling, W.H. 1976. Theory of the Firm: Managerial Behaviour, Agency Costs, and Ownership Structure, Journal of Financial Economics (3): 305-360.

10. Lasher, W.R. (2000). Practical Financial Management. 2 nd Edition. United States of America. SouthernWestern-Thomson Learning.

11. Lewellen, W.G. 1971 (May). A Pure Financial Rationale for the Conglomerate Merger. Journal of Finance, 521-537.

12. Mat Nor, Fauzias. 1995. Post Performance of Malaysian Acquired Firms. Jurnal Pengurusan (Universiti Kebangsaan Malaysian), 14(1) 3-10.

13. Mat Nor, Fauzias. 2003. Malaysian Mergers \& Acquisitions: Theory and Selected Cases: Prentice Hall.

14. Mueller, D.C. 1977. The Effects of Conglomerate Mergers: A Survey of the empirical evidence. Journal of Banking and Finance 1: 315-347.

15. Mueller, D.C. 1969 (Nov). A Theory of Conglomerate Marger: Quarterly. Journal of Economics, 643-659

16. Shanmugam. M. 2000. Merger by decree. Journal of Malaysian Business. Vol. 10. 11-3.

17. The Star. 1999 (August, 11). Bank Negara explains rationale for bank merger.

18. Weston, J.F \& Brigham, E.F. 1975. Managerial Finance. 5 th Edition. Illinois, United States of America. Dryden Press.

19. http://www.bnm.gov.my

20. http://www.klse.com.my

\section{APPENDICES}

\section{Appendix 1: Efficiency Theory (Financial Synergy) Theoretical Framework}

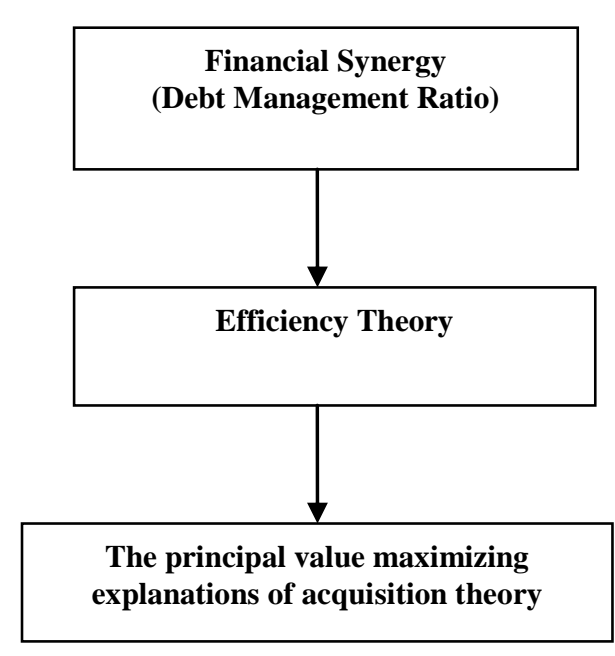

\section{Appendix 2: List of Ten Malaysian Anchor Banks and Abbreviation}

1. Affin Bank Berhad (Affin Bank)

2. Alliance Bank Berhad (Alliance)

3. AM Bank Berhad (AMB)

4. Bumiputera Commerce Bank Berhad (BCB)

5. EON Bank Berhad (EON)

6. Hong Leong Bank Berhad (Hong Leong)

7. Malayan Banking Berhad (Maybank)

8. Public Bank Berhad (Public Bank)

9. RHB Bank Berhad (RHB)

10. Southern Bank Group Berhad (SBB) 


\section{Appendix 3: Financial Data Collected}

1. Net earnings

2. Gross earnings

3. Interest charges

4. Total assets

5. Total liabilities

6. Total shareholders fund

7. Net cash from operating activities

NOTES 